\title{
一次元不定流計算に基づく堤防越流時間の 推定と簡易評価法の検討 \\ EVALUATION OF OVERFLOW DURATION ON RIVER LEVEE BASED ON 1D UNSTEADY FLOW ANALYSIS AND DEVELOPMENT OF SIMPLE METHOD
}

\author{
服部泰士 ${ }^{1} \cdot$ 二瓶泰雄 ${ }^{2} \cdot$ 大槻順朗 $^{3} \cdot$ M.A.C Niroshinie $^{4}$ \\ Taito HATTORI, Yasuo NIHEI, Kazuaki OHTSUKI and Niroshinie M.A.C \\ 1学生員 学 (工) 東京理科大学大学院 理工学研究科土木工学専攻修士課程 \\ （干278-8510 千葉県野田市山崎2641） \\ 2正会員 博 (工) 東京理科大学教授 理工学部土木工学科（同上） \\ ${ }^{3}$ 正会員 博 (工) 東京理科大学助教 理工学部土木工学科 (同上) \\ 4正会員 Ph.D 東京理科大学PD研究員 理工学部土木工学科（同上）
}

\begin{abstract}
Riverbank failures by overflow erosion are frequently occurred by extreme floods. However, studies of the relationship between hydraulic conditions, material conditions and levee failures by overflow erosion is insufficient, specially, the relationship between overflow duration and levee failures by overflow erosion. In the present study, we estimated overflow duration that is difficult to measure in the field surveys, by the one-dimensional simulation of unsteady flow. From that, a simplified estimation method of overflow duration is proposed. The results indicated that the simulation of this study can reproduce overflow duration in extreme flood. Furthermore the simplified estimation method of overflow duration is valid.
\end{abstract}

Key Words: river levee, overflow duration, overflow depth, flood, breach

\section{1. 序論}

2015 年関東・東北豪雨災害では，鬼怒川左岸 $21 \mathrm{~km}$ 付近 で決壊し，大量の河川水が決壊地点から堤内地側に非常 に大きな速度で流入し周辺家屋を土台ごと流失させたこ とは記憶に新しい1)。このように，河川堤防を越流し， その後, 堤防の一部が決壊すると，人的・物的被害の深刻 化につながることが多い2，3)。現在，首都圏では，荒川 や利根川の決壊やそれに伴う広域かつ長期間の洪水汇濫 が危惧されている4).

河川堤防の設計では, 計画高水位以下の地震動, 洗掘, 浸透に耐えることを前提としているため，長時間越流す ることを想定して設計されていない5，6)，そのため，堤 防の耐越流対策は一般に不十分であり，堤防の決壊要因 としても越流は浸透や洗掘よりも寄与が大きい7)。この ようなことから, 而越流侵食性強化技術の開発 (例えば, GRS 河川堤防 ${ }^{8)}$ ) を行うことのみならず, 長大な堤防強化 を一律に行うことが困難な現状を鑑みて，既存河川堤防 において決壊危険度の高い弱点箇所を抽出可能とする調 査研究や技術開発が強く求められている.

この状況に対して，堤防全体における決壊危険度評価
の試みが最近なされつつあり，浸透決壊に関しては田端 らの研究 9), 10) , 越流決壊に関しては著者らの取り組み ${ }^{11)}$ (以下, 前報と呼ぶ) が挙げられる.このうち後者では, いくつかの水害調査から河川堤防の越流決壊・破損の情 報を収集するとともに，合わせて水理条件（越流水深な ど）や堤体条件（高さ，天端幅，勾配，のり面の被覆状況 など）も収集した堤防決壊データベースを作成し，水理・ 堤体条件と堤防決壊状況との関係を検討している. しか しながら，前報では，水理条件として現地で得られる越 流水深 (洪水痕跡から求めた值) のみを扱っていたが，他 の重要なパラメータである越流時間に関しては現地計測 できないため, 前報のデータベースには含まれていない. また，吉川7)による堤防決壊判定条件にも越流水深と越 流時間が指標として用いられ，今後，越流決壊判定を行 うには越流時間データを何らかの形で取得するか，もし くは別途評価する簡易法を検討する必要がある.

本研究では，一次元河川不定流シミュレーションに基 づて洪水時における河道部の水位を再現し，その結果 に基づいて現地調査では評価困難な堤防上の越流時間を 推定することを試みる。 また，対象区間内に水位観測所 
表-1 数值シミュレーションの概要

\begin{tabular}{|c|c|c|c|c|}
\hline 河川名 & 須佐川 & 田万川 & 原中川 & 吉野川 \\
\hline 区間 & 河口部〜 $1.8 \mathrm{~km}$ & 河口から $9.7 \mathrm{~km} 〜 22.2 \mathrm{~km}$ & 田万川合流部〜 $4.7 \mathrm{~km}$ & 最上川合流部〜 $8.1 \mathrm{~km}$ \\
\hline 期間 & \multicolumn{3}{|c|}{ 2013/7/28 0:00〜 7/29 0:00 } & 2014/7/9 0:00〜 7/11 0:00 \\
\hline 流入条件 & 上流域 $11.3 \mathrm{~km}^{2}$ & $\begin{array}{c}\text { 上流域 } 51.7 \mathrm{~km}^{2} \\
\text { 田万川・宇谷川流域 } 22.3 \mathrm{~km}^{2} \\
\text { (河口から } 14.8 \mathrm{~km} \text { 地点合流) } \\
\text { 大浴川流域 } 3.0 \mathrm{~km}^{2} \\
(\text { 河口か } 11.7 \mathrm{~km}) \\
\text { 大山田川流域 } 11.6 \mathrm{~km}^{2} \\
\text { (河口から } 10.2 \mathrm{~km}) \\
\end{array}$ & $\begin{array}{c}\text { 上流域 } 19.3 \mathrm{~km}^{2} \\
\text { 宇谷川 流域 } 3.0 \mathrm{~km}^{2} \\
\text { (合流部か } 51.7 \mathrm{~km} \text { ) }\end{array}$ & 上流域 $71.6 \mathrm{~km}^{2}$ \\
\hline 下流水位 & +1.5 T.P.m & 等流水深 & 等流水深 & 観測值 (内挿値) \\
\hline
\end{tabular}

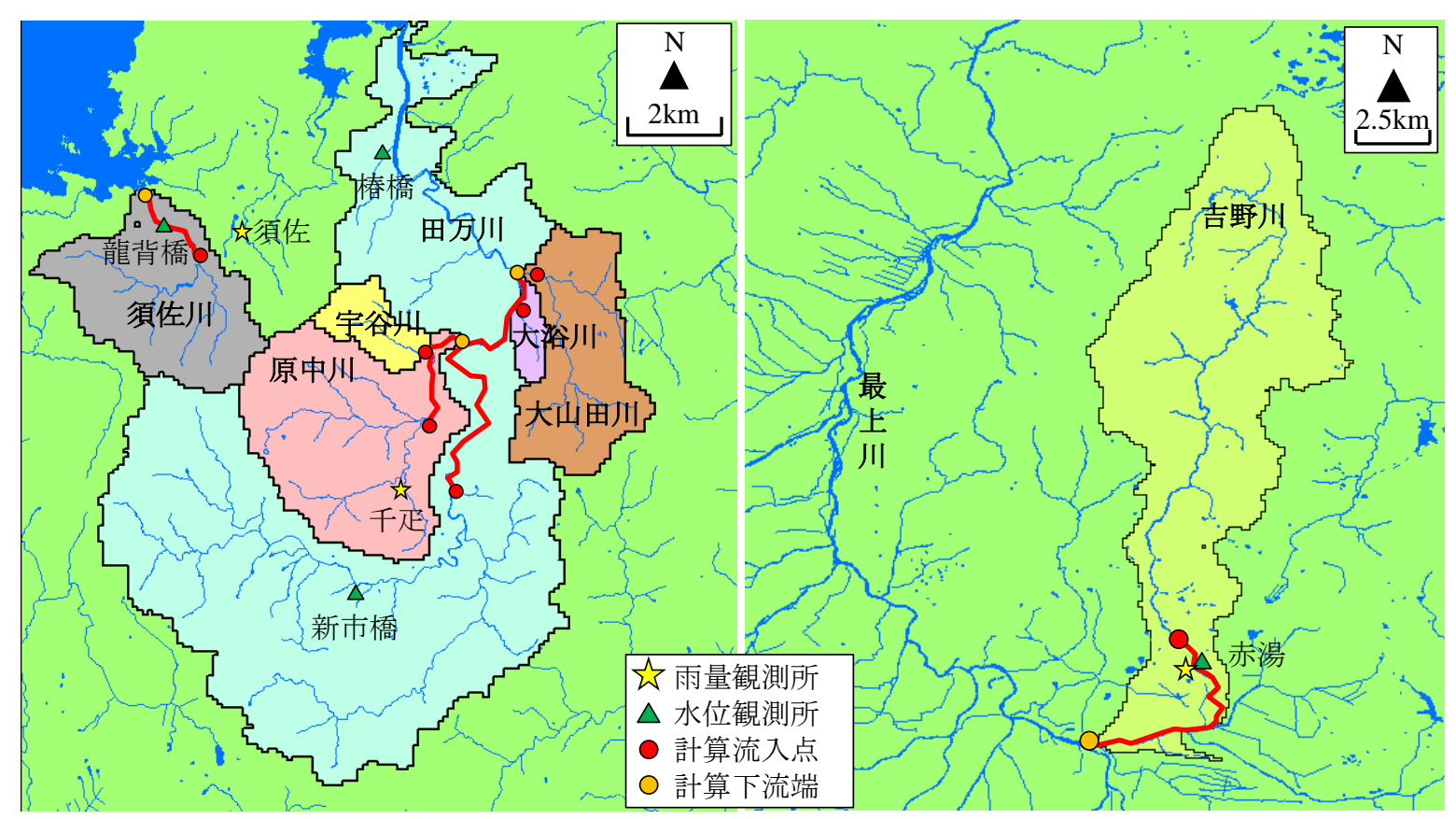

図-1 一次元河川不定流計算における計算範囲（赤太線 : 計算区間）

がある場合を想定して，水位観測所における水位時系列 データのみから簡便に越流時間を推定する方法を提案し, その有効性を前述の数值計算結果等を用いて検証する.

\section{2. 研究方法}

\section{（1）数值シミュレーション手法の概要}

本研究では，対象河川における洪水流再現シミュレー ションを行うに当たり，(1)対象区間上流域もしくは支川 における降雨流出シミュレーションと，(2)対象区間の一 次元河川不定流シミュレーション，の二つの数值シミュ レーションを行う。(1)の降雨流出解析では, 汎用水理水 文モデルであるMIKE112) の降雨流出モデルUrban model(A) を用いた。 (2)の一次元不定流解析においても, 同じ MIKE11の一次元洪水流解析ツールを使用した. 一次元河 川不定流解析では，境界条件としては，上流端の流量条 件には(1)の降雨流出モデルの計算結果を与え, 下流端の 水位条件では計算対象毎に別々に与えた。これらのモデ
ル構成の詳細は，参考文献12 を参照されたい。なお，本 論文では，簡便な一次元解析を行うため堤防上の横越流 を考慮していないが，最高水位の縦断分布再現を主目的 としているため本論文の趣旨には問題ない.

\section{（2）対象サイトと計算概要}

堤防上の越流時間を算出するための計算対象サイトは, 前報において越流水深などの堤防被災状況データベース が得られている，山口県萩市の須佐川，田万川とその支 川の原中川，山形県南陽市の吉野川の計4河川とする. 前 者3河川では2013年7月の山口・島根豪雨水害13), 後者では 2014年7月山形豪雨水害14) が，それぞれ発生した.

計算対象サイトや数值シミュレーションの概要を表-1 及び関係するマップを図-1に示す.須佐川では, 大槻ら ${ }^{15)}$ と同じく，計算区間は河口から $0.0 \mathrm{~km} \sim 1.8 \mathrm{~km}$ であり，区間 内への流入は上流端のみである. 下流端は河口部に相当 するため一定水位（=1.5[T.P.m]）を与えた。計算期間は 2013/7/28 0:00～24:00である. ここでの流出解析に用いる 


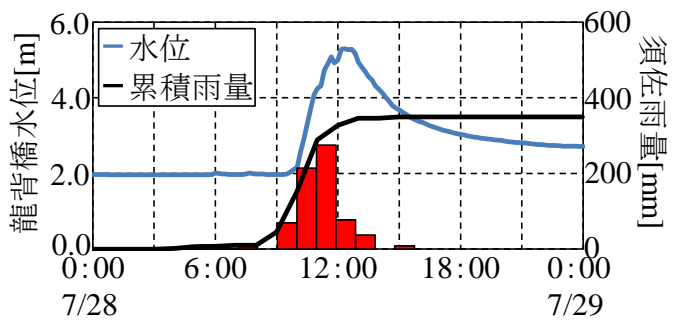

(a) 須佐川（2013 年）

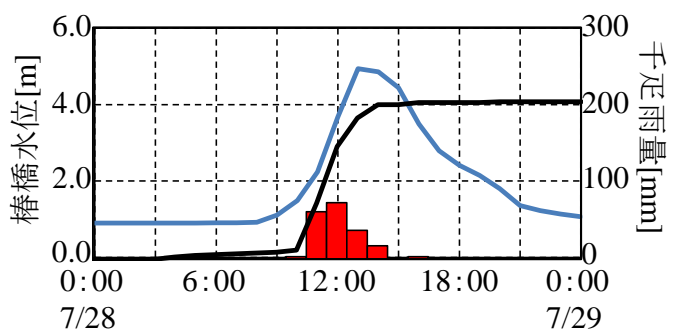

(b) 田万川・原中川（2013 年）

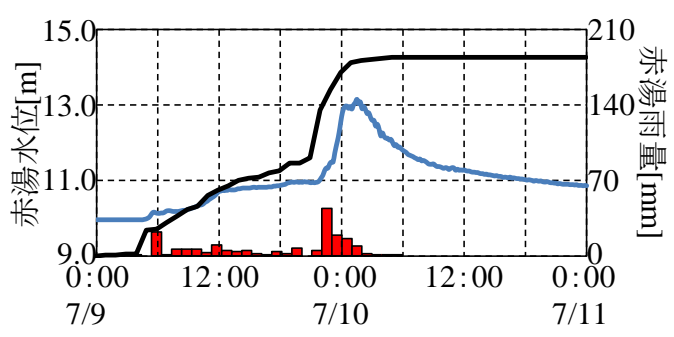

(c) 吉野川 (2014 年)

図-2 研究対象洪水の概要

雨量データは須佐観測所（図-2（a)）のものであり，水位 観測所データ（龍背橋，河口から $0.5 \mathrm{~km}$ ）は検証用データ に用いる。

田万川とその支川の原中川に関しては，田万川本川と 原中川の二つに区間分けする. まず，田万川本川（図-1中 赤色の太線）については，河口から9.7km〜22.2kmを計算 区間とする. 流入点は, 上流端に加えて, 原中川・宇谷川 流域 $(14.8 \mathrm{~km}$ 地点合流)，大浴川流域 (同11.7km)，大山 田川流域 (同10.2km) である. 雨量は千正観測所データ（図 -2(b)）を用いる. 計算区間下流端には岡平水位観測所が あるが，豪雨期間中に欠測が生じたので，本計算では用 いず，等流水深を与えることとする. 次に支川の原中川 に関しては，田万川合流点から4.7kmまでを計算区間とし， 流入点は上流端と宇谷川流域 (合流点加ら $1.7 \mathrm{~km})$ とする.

下流端の水位条件としては，上述した田万川本川の計算 結果のうち，原中川合流点の計算水位を用いる．計算時 間は田万川, 原中川共に2013年7月28日から24時間とする.

最後に，山形県吉野川に関しては，最上川合流点から $8.1 \mathrm{~km}$ までを計算対象区間とし，流入点は上流端のみであ る. 雨量データは図-2 (c) に示寸赤湯雨量観測所の結果を 用いる. 下流端水位は, 最上川における水位観測点のデ

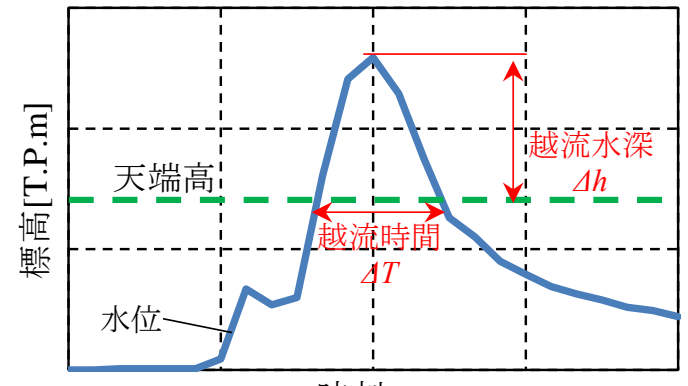

時刻 [s]

図-3 越流時間・水深の定義

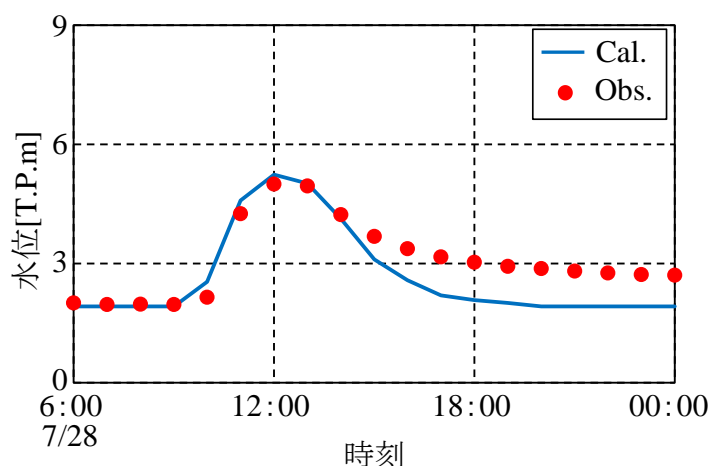

（a）須佐川 龍背橋（2013 年）

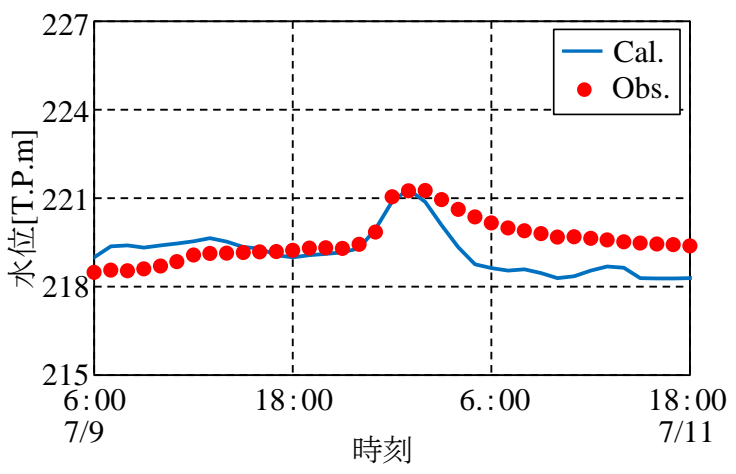

(b) 吉野川 赤湯（2014 年）

図-4 水位時系列データの計算值と観測值の比較

ータを吉野川合流地点に内挿した結果を与えた。計算期 間は2014年7月9日から2日間である.

得られた計算結果を, 多くの地点における越流水深の 観測值や水位観測所の水位時系列データと比較・検討し, シミュレーション結果の妥当性を検証する. その後, 計 算された水位データから，図-3 に示寸ように越流時間を 定義して，越流箇所の越流時間を算出する.

\section{3. 結果と考察}

（1）本一次元河川不定流シミュレーションの精度検証

各河川における越流時間を求める前に，一次元河川不 定流シミュレーションの有用性を検証するべく，計算範 囲に水位観測所がある須佐川と吉野川での水位時系列デ 一タの観測值と計算值の比較を図-4に示寸。ここで, 須 佐川では龍背橋, 吉野川では赤湯 (図-1) の結果を示寸. これより，両河川ともに増水期や水位ピーク期では水位 


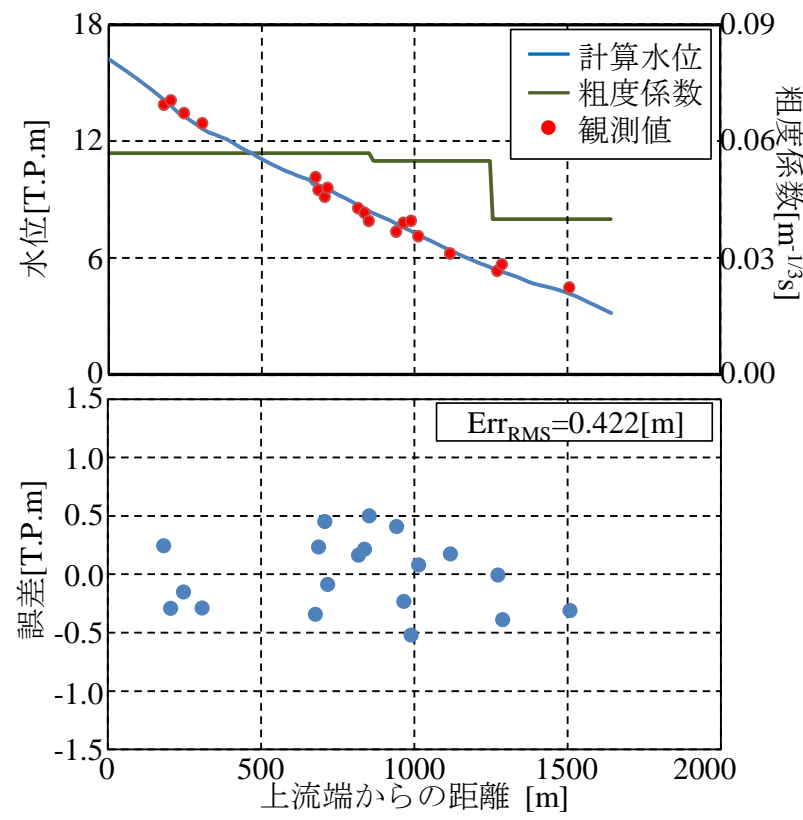

(a) 須佐川
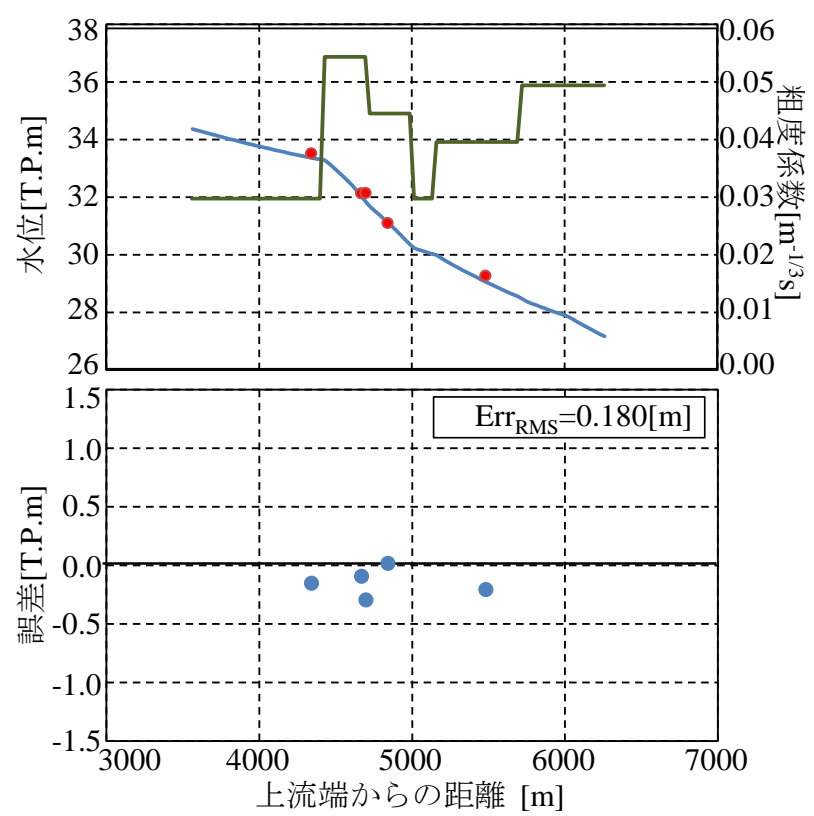

(b) 田万川

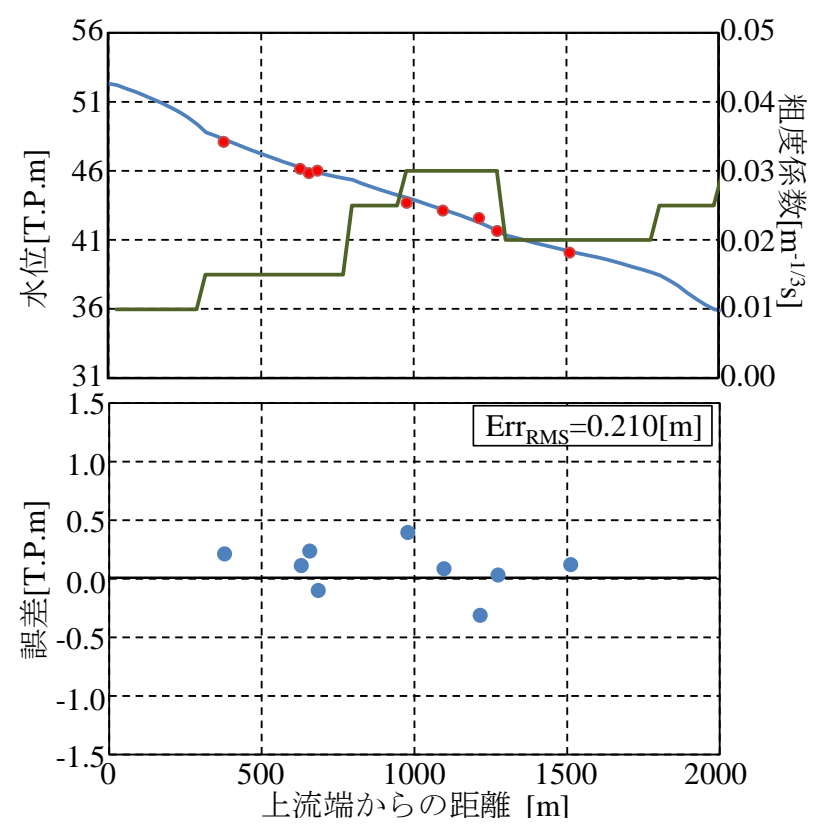

(c) 原中川

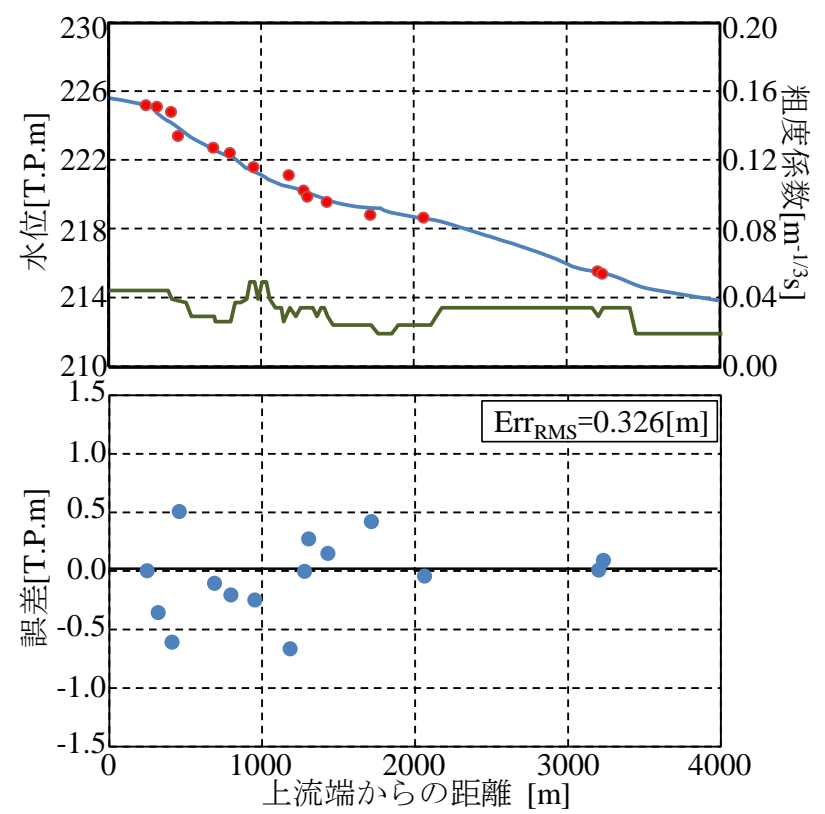

(d) 吉野川

図-5 対象洪水時の最高水位の計算値と観測值（痕跡水位）と両者の差（二計算值-観測値），計算で用いた二粗度係数の縱断分布

の観測值と計算値は良好に一致するが，減水期では両者 の一致度合いは低下寸る.これは, 粗度係数等のパラメ 一夕同定には増水期や水位ピーク期の水位を合わせるた め，減水期の精度が低下している．後述の越流時間を求 める際には，水位ピーク期付近のデータのみ参照するた め，減水期での再現性の低下は本論文の範囲では問題な い. また，洪水中に橋梁部での流木捕捉や河川内一の家 屋流出 (須佐川) 等, 河道内の抵抗状況が洪水中に大きく 変化していることも考えられる.

次に, 洪水中における最高水位の計算結果と観測值 (痕 跡水位) の縦断分布を図-5に示寸．ここでは，各河川に おける最高水位の計算值の誤差（=計算値一観測值）の 縦断分布も合わせて表示寸る. なお，ここでの最高水位
の観測值は，いずれも，堤防を越流した地点の痕跡水位 を用いている.また，計算で用いられた粗度係数の縦断 分布も合わせて示す.これより,4つ全ての河川において, 最高水位の計算結果は観測值を概水トレースできている ことが分かる. また, 最高水位の計算值と観測值の差は, 須佐川・原中川ではほぼ $\pm 0.5[\mathrm{~m}]$ 以内, 田万川では $\pm 0.2[\mathrm{~m}]$ 以内, 吉野川では土0.7[m]以内である. 両者の差の RMS 值 は, 須佐川では 0.42[m], 田万川では 0.18[.m], 原中川では $0.21[\mathrm{~m}]$, 吉野川では $0.33[\mathrm{~m}]$ となり，概衫良好な結果とな った. このことから，各河川における一次元不定流計算 結果は概水妥当であり, 洪水時の最高水位の縦断分布を 概ね再現でき, 以下の水位計算值から越流時間を求めて も問題ない. 


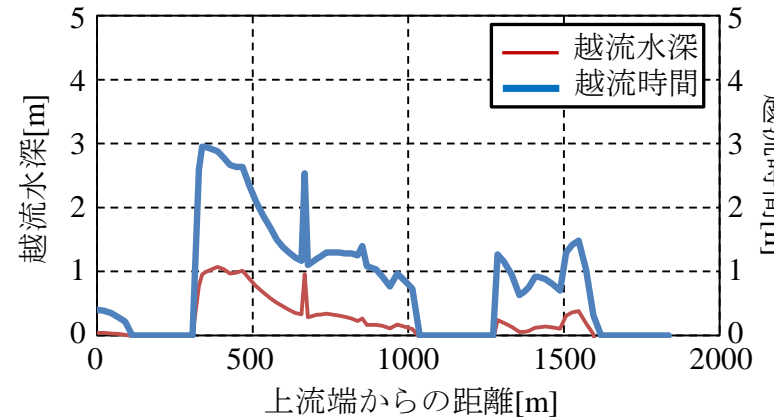

(a) 須佐川

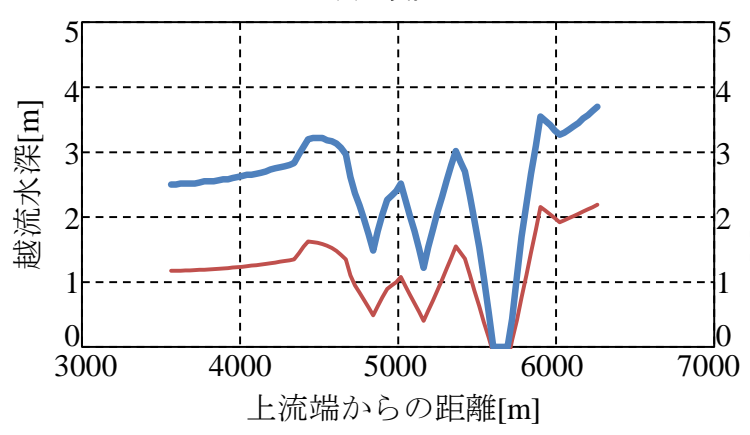

(b) 田万川

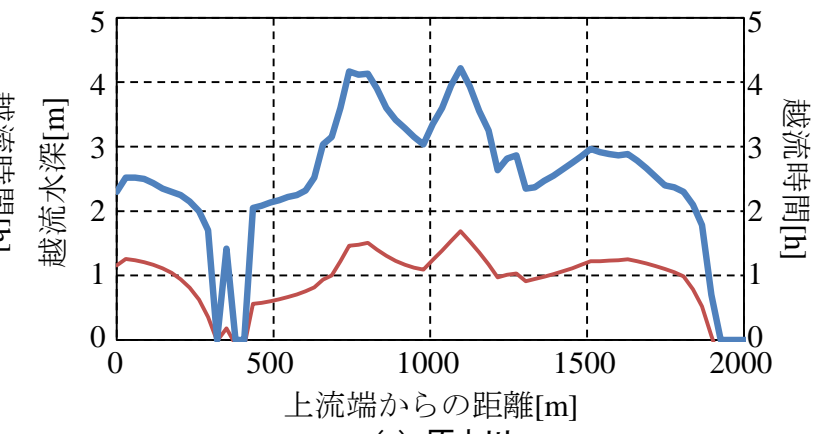

(c) 原中川

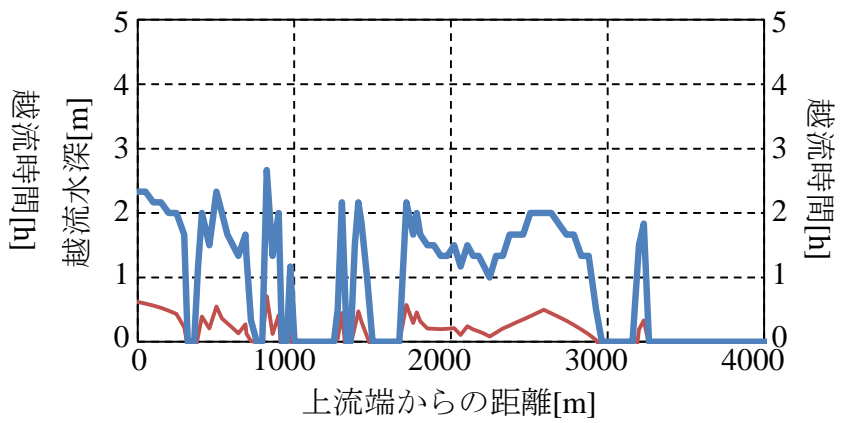

（d）吉野川

\section{図-6 越流水深と越流時間の縱断分布}

なお, 吉野川に関しては, 観測值の再現性が悪いところ が何か所か存在している，吉野川における計算対象区間 は, 他の河川と比べて, 相対的に, 蛇行・湾曲している部 分が多い，そのため，吉野川において堤防の左右岸の堤 防上の越流水深・水位データを詳細に取得し, 比較した 結果，堤防の左右岸における痕跡水位の差が生じている 断面があることが分かった. 今回の数值シミュレーショ ンは一次元不定流解析であるので，河道の湾曲などに起 因する左右岸の水位差は考慮できておらず, 結果として 最高水位の再現性が若干低下したものと推察される.

\section{（2）越流時間と水深の縱断分布}

一次元河川不定流シミュレーションにより得られた越 流水深と越流時間の縦断分布を図一6には示す。ここでも 計算対象の4河川の結果を図示している.この越流水深や 越流時間の算出は，図-3に従っている. 実際には，一部の 区間では堤防の破損や決壊による堤体高さの減少やそれ に伴う越流時間がより長くなることがあるが，ここでは それらの影響は加味していない. なお, ここでは, 各河川 共に左岸の結果を表示している. これより, 越流水深の 増減は越流時間の増減と概ね類似しており，本計算にお いて越流水深と越流時間の相関関係があることが伺える。 また, 河川間での結果を比べると, 吉野川では, 越流水深 が概ね $70 \mathrm{~cm}$ 以下であり越流箇所が離散的に存在している が，田万川や原中川では越流水深が $1 \mathrm{~m} を$ 多く, 長区間にわたり越流していることが分かる. また, 須佐川では, 計 3 箇所の越流区間が発生している. また, これらの河川では越流時間が1〜4時間にも達しているこ

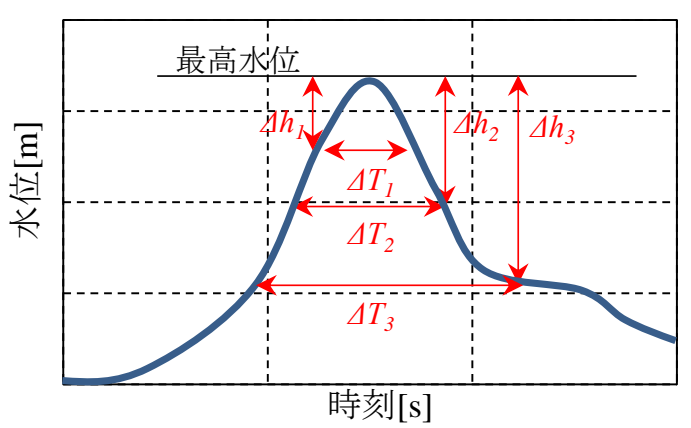

図-7 越流時間の簡易推定法の概略

とが分かる．このように，一次元河川不定流シミ ユレーションを行い, 痕跡水位を合わせることにより， 信頼性の高い越流水深や越流時間を算出できることが示 された. なお，河川毎に見ると越流水深と越流時間は明 確な相関関係が確認された $\left(R^{2}=0.60 \sim 0.82\right)$.

\section{（3）越流時間の簡易推定法の概要と精度検証}

洪水汇濫が発生し, 堤防を越流した場合, 毎回, 本研究 のように一次元不定流計算を行い, 越流時間を算出する には一定の労力を要する. そこで, 堤防上の越流水深の 観測值と水位観測所における水位時系列データのみから 越流時間を簡便に算出する手順を以下に示す.

(1) 水位観測所の実測值から, 最高水位との差 $\Delta h$ とその 継続時間 $\Delta T の$ 相関図を作成する（図-7）。また両者間 の近似式を求める.

(2) 堤防上の越流水深の観測值を上記の $\Delta h$ 見立てて, 上記の近似式に代入して得られる継続時間 $\Delta T$ を越流 時間として求める. 


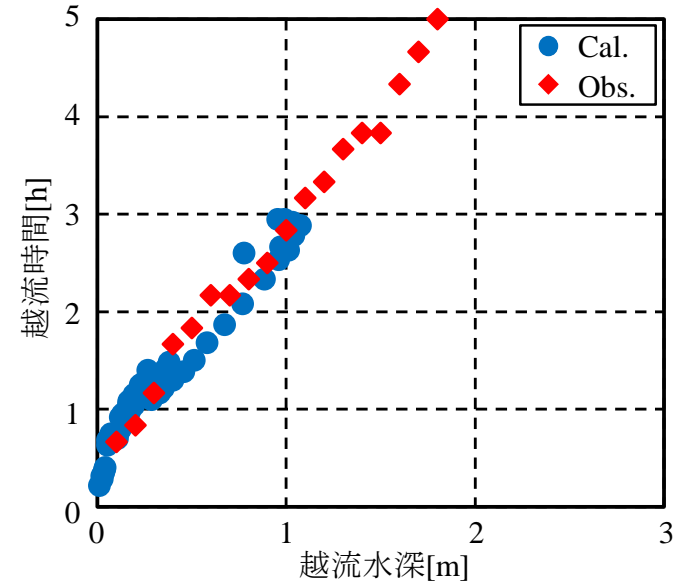

(a) 須佐川

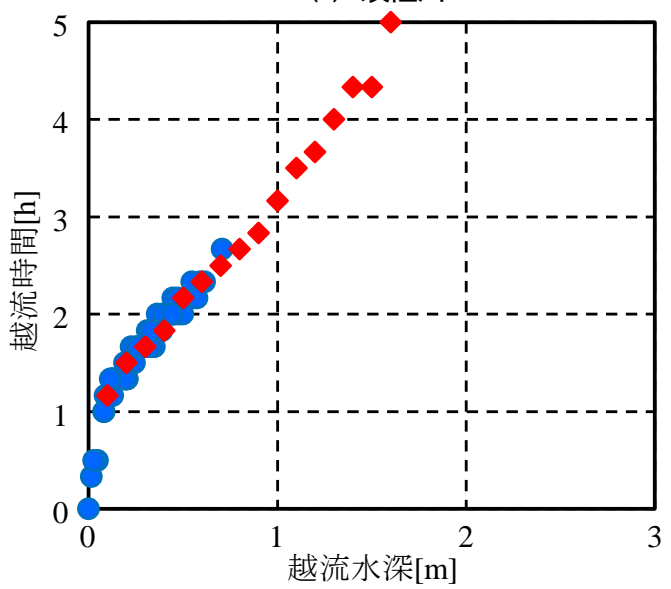

(b) 吉野川

図-8 越流水深と越流時間の相関図 (Cal. : 数値計算結果, Obs：水位観測所の実測值)

この方法では，水位観測所における水位差 $\Delta h$ と継続時 間 $\Delta T の$ 相関関係と実測の越流水深データから越流時間を 求めることができるため, 簡便かつ現実的な手法といえ る. 本手法の精度検証を行うために，根幹である(1)の水 位観測所での水位時系列から求めた水位差 $\Delta h$ と継続時間 $\Delta T の$ 相関関係と, 本一次元解析において得られた越流時 間と越流水深の相関関係を重ねて表示したものを図-8に 示す.ここでは，水位観測所がある須佐川と吉野川の結 果を図示する。これより, 水位時系列データより求めた 水位差 $\Delta h$ と継続時間 $\Delta T$ の相関関係は，計算結果に基づく 越流時間と越流水深の相関関係と良好に一致しているこ とが分かる。これより，本手法により，簡便に越流時間を 評価できることが明らかとなった，ただし，本研究対象 の洪水では越流水深が1mを越えるデータが少なく, 減水 期の水位時系列波形の再現性が低いことから，越流水深 が1m以上の範囲では越流時間の推定を良好に行えるかは 不明であり，今後，詳細に検討する予定である.

\section{4. 結論}

本研究で得られた主な結論は以下のとおりである.
1）本一次元河川不定流シミュレーションの計算結果は 洪水痕跡から推定された越流水深の最高水位や水位 時系列データと概ね一致しており，洪水時の越流水 深・時間を再現できていることが示された.

2）水位時系列データと越流水深のみを用いる越流時間 簡易推定法は，本一次元河川不定流シミュレーショ ン結果と良好に一致しており，本簡易手法の有効性 が示された。

謝辞: 本研究の一部は, 科学研究費補助金・基盤研究 (B)

(研究代表者 : 二瓶泰雄)，河川財団河川整備基金（研究 代表者: 二瓶泰雄) によって実施された.ここに記して深 甚なる謝意を表します.

\section{参考文献}

1) 国土技術研究センター: 台風 17 号及び 18 号による鬼怒 川被害現地調查報告 〜平成 27 年 9 月 10 日の大雨による被 害〜, 2015.

2) 福成孝三，白井勝二，吉川克秀 : 河川堤防システムの安全 管理に関する実証的研究，建設マネジメント研究論文集 Vol.14, pp.311-pp.320, 2007.

3) 内閣府 : http://www.bousai.go.jp/kaigirep/chuobou/senmon/dai kibosuigai/pdf/100402_kisya.pdf (閲覧日:H27年9月 21 日)。

4) 池内幸司, 越智繁雄, 安田吾郎, 岡村次郎, 青野正志 : 大規 模水害時における孤立者数・孤立時間の推計とその軽減方 策の効果分析，土木学会論文集 B1 (水工学)，Vol.67, No.3, pp.145-154, 2011.

5) (社)日本河川協会編 : 改訂新版建設省河川砂防技術基淮(案) 同解説設計編 [ ] , pp.3-30, 1997.

6) 土木学会 : 水理公式集 [平成 11 年版]，丸善, pp.194-205, 1999.

7) 吉川勝秀（編著）：河川堤防学新しい河川工学，技報堂出 版, 98 p., 2008.

8）倉上由貴，二瓶泰雄，矢田孝次朗，山崎達也，山口晋平，川 邊翔平，菊池喜昭，龍岡文夫 : 而越流侵食性向上のための 河川堤防補強技術の提案，土木学会論文集 B1（水工学）, Vol.69, No.4, pp.I-1219-I-1224, 2013.

9）田端幸輔，福岡捷二，中平善伸 : 複雑な河道システムを有 する信濃川下流域の治水機能の評価と今後の治水対策のあ り方，土木学会論文集 B1（水工学），Vol.70, No.4, ppI-1483I-1488, 2014.

10）田端幸輔，福岡捷二，瀬崎智之 : 超過洪水時における堤防 破堤確率評価手法に関寸る研究，土木学会論文集 B1（水工 学), Vol.71, No.4, pp.I-1273-I-1278, 2015.

11）服部泰士，二瓶泰雄，大柣頑朗，八木澤順治 : 実測データ ベースに基づく河川堤防の越流決壊・破損条件の検討，土 木学会論文集 B1（水工学），Vol.71，pp.I-1285-I-1290，2015.

12) MIKE by DHI 2012 : MIKE11 A modellimg system for Rivers and Channels UserGuide, pp.1-544, 2012.

13) 土木学会水工学委員会山口・島根水害調査団 : 平成 25 年 7 月 28 日山口・島根豪雨災害調查報告（速報版）， http://committees.jsce.or.jp/report/system/files/201307yamaguchishimane.pdf, 2013.

14) 東北大学災害科学国際研究所緊急苂害調査団 : 平成 26 年 7 月山形豪雨・土砂災害緊急調査報告書（速報）, http://irides.tohoku.ac.jp/media/files/topics/yamagata-flood_201407_v3.pdf.

15）大槻順朗，二瓶泰雄，赤松良久：2013 年 7 月山口・島根豪 雨による須佐川における被災状況調査と解析，土木学会論 文集 B1（水工学），Vol.70， No.4，pp.I-1447-I-1452， 2014.

(2015.9. 30 受付) 